УДК 536.242; 536.4

\title{
ВИКОРИСТАННЯ МЕТОДІВ ТЕРМОКОНТАКТНОГО НАГРІВАННЯ ТА ДИСКРЕТНО-ІМПУЛЬСНОГО ВВЕДЕННЯ ЕНЕРГІЇ В ТЕХНОЛОГІЇ ОДЕРЖАННЯ СУПОЗИТОРІЇВ
}

\author{
Грабов Л.М., канд. техн. наук, Посунько Д.В., Степанова О.С. \\ Інститут технічної теплофізики НАН Украӥни, вул. Желябова, 2а, Київ, 03680, Украӥна
}

Представлено аналіз традиційної технології отримання супозиторних лікарських форм та інноваційні методи і устаткування, які розроблені в ІТТФ НАНУ.

Бібл. 9, табл. 1, рис. 7.
Представлен анализ традиционной технологии получения суппозиторных лекарственных форм и инновационные методы и оборудование, которые разработаны в ИТТФ НАНУ.
The analysis of the traditional technology of suppository medicinal forms and innovative techniques and equipment that are developed in IET NASU.

Ключові слова: нагрівання, плавлення, диспергація, гомогенізація, супозиторії, гідрофільні, гідрофобні та дифільні основи.

GMP - Good Manufacturing Practice (Належна виробнича практика);

ДІВЕ - дискретно-імпульсне введення енергії; ITТФ - інститут технічної теплофізики;

ЛР - лікарські речовини;

Супозиторії - це дисперсні системи, що складаються з основи (дисперсійної фази) і лікарських речовин (дисперсної фази). Вони є твердими при кімнатній температурі, а при температурі тіла розплавляються для вивільнення лікарських речовин (ЛР). Такі системи є складними багатокомпонентними гетерогенними системами, так як містять одну або більше лікарських речовин, диспергованих або розчинених у простій або складній основі, яка може розчинятися або диспергуватися у воді.

Супозиторії набувають все більшого поширення в фармації та медицині завдяки високій швидкості всмоктування лікарських речовин та можливості суміщення в супозиторіях інгредієнтів 3 різноманітними фармакологічними та фізико-хімічними властивостями. Промислове виробництво супозиторіїв в Україні розпочалось з 1994 року. На фармацевтичному ринку України зараз представлені супозиторні лікарські форми (ЛФ) близько 50 відомих фармацевтичних фірм із 23 країн (лідери: Німеччина,
ЛФ - лікарські форми;

НАНУ - Національна академія наук України;

ПАР - поверхнево-активні речовини;

ПЕО - поліетиленоксиди;

ККД - коефіцієнт корисної дії.

Франція, Італія і Швейцарія) і тільки 5 вітчизняними фірмами: “Лекхім” (м. Харків), “Монфарм” (м. Монастирище), “Фітолек” (м. Харків), "Сперко Україна" (м. Вінниця), “Фармекс Груп” (м. Бориспіль) [1]. Застарілі технології та устаткування для виготовлення супозиторіїв зумовлюють закупівлю та експлуатацію імпортного обладнання з Німеччини, Італії, США і інших країн. Необхідність розробки і впровадження високоефективних інноваційних технологій та обладнання для виробництва супозиторних ЛФ обумовлена потребою населення в вітчизняних фармацевтичних препаратах.

Актуальною задачею $є$ апаратурно-технічне переоснащення діючих виробництв, створення нових виробничих потужностей у фармацевтичній галузі відповідно до правил належної практики виробництва (GMP) супозиторних лікарських форм.

В основу технології отримання супозиторних ЛФ (рис. 1) входить комплекс тепломасообмінних процесів: теплопередача при нагріванні, 
охолодженні та плавленні; перемішування і розчинення; диспергування (збільшення поверхні розділу фаз) та гомогенізація; структурування (отримання зв'язно-дисперсної системи); екстра- гування (конвективна та молекулярна дифузія, а також перенос речовини, яку витягують, 3 твердої фази в рідку).

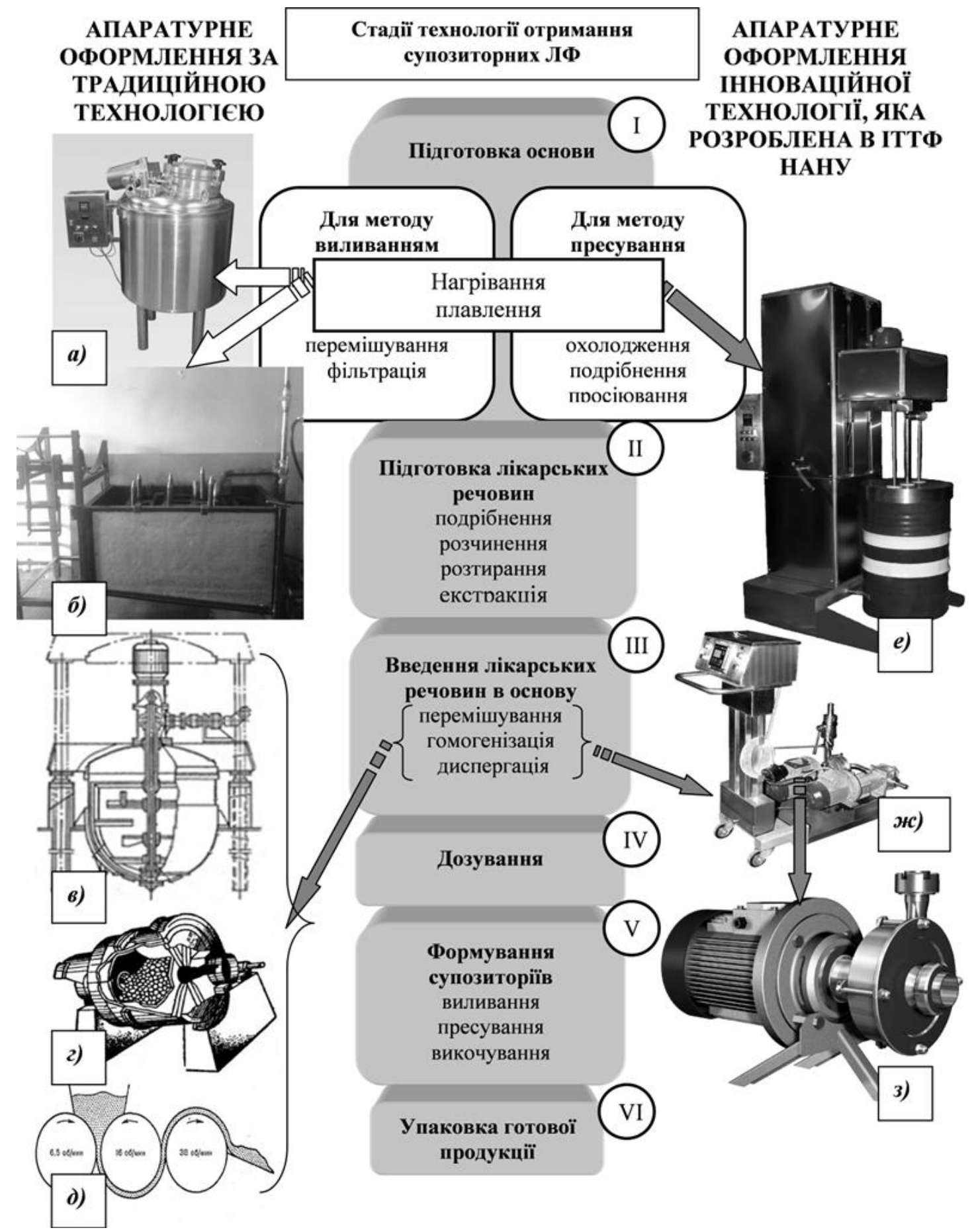

Рис. 1. Блок-схема та апаратурне оформлення технології виготовлення супозиторіїв:

а) реактор з мішалкою; б) ванна із змійовиком; в) реактор із мішалками; г) кульовий млин;

д) трьохвальцьова мазетерка; е) установка “Термобат-М"; ж) мобільний агрегат “Фарматрон-3000”; з) гомогенізатор-диспергатор “АР-3000”. 


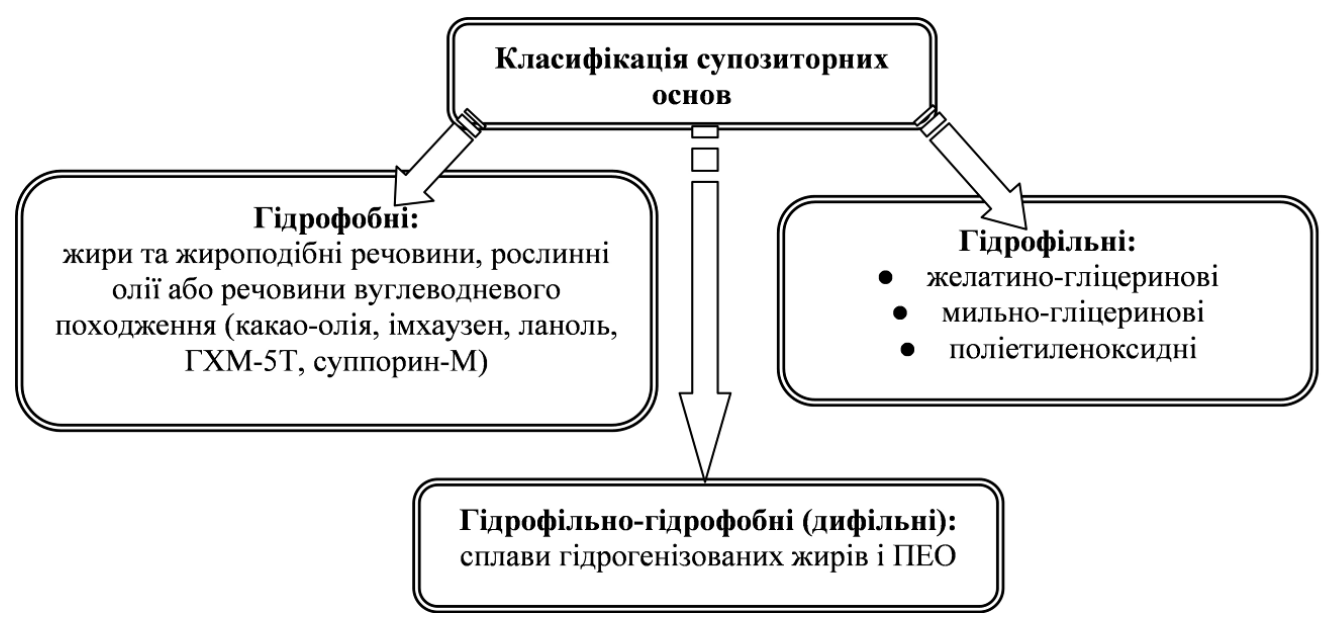

Рис. 2. Класифікація супозиторних основ.

Реологічні параметри супозиторних основ та їх сумішей з допоміжними речовинами, що застосовують у виробництві супозиторіїв, важливі при виборі виробничого обладнання, необхідного для виконання того або іншого технологічного процесу (плавлення, змішування, гомогенізації, диспергування). Найбільш важливими чинниками для супозиторних форм є ступінь дисперсності діючих речовин, спосіб введення їх в основу, час, швидкість, температурний режим і порядок змішування компонентів. Усе це впливає на реологічні властивості, однорідність, стабільність при зберіганні і ефективність супозиторіїв.

Першою і важливою стадією в технології отримання супозиторних ЛФ є підготовка супозиторних основ (рис. 1, стадія I). Зліва представлено апаратурне оформлення за традиційною технологією одержання супозиторіїв, а з правої апаратурне оформлення інноваційної технології, яка розроблена в ІТТФ НАНУ.

В залежності від фармакологічної дії супозиторіїв застосовуються гідрофобні, гідрофільні основи та їх суміші (рис. 2). Деякі проблеми виникають при отриманні стабільних дифільних основ, які містять гідрофільну i гідрофобну частини, але такі основи дають можливість вводити в них як жиро-, так $\mathrm{i}$ водорозчинні ЛР та їх розчини.

Значення i роль основ в технології супозиторіїв важливі і різноманітні. Основи забезпечують необхідну масу супозиторіїв i відповідно належну концентрацію лікарських речовин, м'яку консистенцію, істотно впливають на їх стабільність. Ступінь вивільнення лікарських речовин з супозиторіїв, швидкість і повнота їх всмоктування багато в чому залежать від природи, складу і властивостей основи.

У таблиці 1 представлені сучасні супозиторні основи, 3 якої видно різноманітність складу основ та широкий діапазон температур плавлення (твердіння), що необхідно враховувати при складанні композиції супозиторної основи $[2,3]$. Це потрібно для того, щоб отримати багатокомпонентну супозиторну основу 3 необхідними структурно-механічними властивостями.

Одними з важливих теплообмінних процесів на цій стадії $\epsilon$ нагрівання та плавлення. За традиційною технологією для нагрівання та плавлення основ на фармацевтичних фабриках використовують реактори з різними видами мішалок (рис. 1, a), ванни із змійовиками (рис. 1, б), електротканні нагрівачі, нагрівальні камери тощо. Але ці методи мають ряд суттєвих недоліків: трудомісткі та енерговитратні; можливий перегрів основи, що призводить до різних змін фізико-хімічних та структурно-механічних властивостей дисперсійної фази; виникнення контамінації; не рівномірний прогрів всієї маси основи. Наприклад, перегрів жирів та жироподібних речовин часто призводить до утворення таких форм, які мають більш низькі температури плавлення, а також супозиторії після перегріву основи нестійкі при зберіганні, так як розплавляться при кімнатній температурі. При цьому речовини втрачають твердість при кімнатній температурі, що виключає можливість 
виготовлення супозиторіїв.

Для усунення цих недоліків фахівцями Інституту технічної теплофізики запропонована модернізація технології з використанням ме- тода термоконтактного нагрівання та плавлення (рис. $1, e)$. Принципова схема установки для термоконтактного нагрівання та плавлення [4] представлено на рис. 3.

Табл. 1. Сучасні супозиторні основи, що використовуються для виготовлення супозиторних ЛФ

\begin{tabular}{|c|c|c|c|c|c|}
\hline \multirow{2}{*}{$\begin{array}{l}\text { Супозиторна } \\
\text { основа }\end{array}$} & \multirow{2}{*}{ Склад } & \multicolumn{3}{|c|}{ Температура плавлення } & \multirow{2}{*}{ Виробник, країна } \\
\hline & & K & ${ }^{\circ} \mathrm{C}$ & ${ }^{\circ} \mathrm{F}$ & \\
\hline \multicolumn{6}{|c|}{ Гідрофобні основи } \\
\hline олія какао & $\begin{array}{c}\text { тригліцериди } \\
\text { жирних } \\
\text { кислот }\end{array}$ & $305 \ldots 307$ & $32 \ldots 34$ & $89,6 \ldots 61,2$ & $\begin{array}{l}\text { Україна, } \\
\text { США та ін. }\end{array}$ \\
\hline бутирол & $\begin{array}{c}\text { гідрогенізовані } \\
\text { жири, парафіни, } \\
\text { какао-олія }\end{array}$ & $308 \ldots 312$ & $35 \ldots 39$ & $95 \ldots 102,2$ & Україна \\
\hline себувінол & $\begin{array}{c}\text { сплав яловичого } \\
\text { жиру }\end{array}$ & $309 \ldots 310$ & $36 \ldots 37$ & $96,8 \ldots 98,6$ & Росія \\
\hline $\begin{array}{c}\text { естарінум } \\
\text { A, B, C, D, E, T }\end{array}$ & $\begin{array}{l}\text { суміш гліцеридів } \\
\text { насичених кислот }\end{array}$ & $302 \ldots 323$ & $29 \ldots 50$ & $84,2 \ldots 122$ & $\begin{array}{l}\text { "Dynamit Nobel } \\
\text { Сhemical", } \\
\text { Велікобританія }\end{array}$ \\
\hline $\begin{array}{c}\text { вітепсол } \\
\mathrm{Y}, \mathrm{W}, \mathrm{S}, \mathrm{E}\end{array}$ & $\begin{array}{l}\text { суміш глицеридів } \\
\text { рослинних кислот }\end{array}$ & $306 \ldots 312$ & $33 \ldots 39$ & $91,4 \ldots 102,2$ & $\begin{array}{l}\text { "Dynamit Nobel } \\
\text { Chemical", } \\
\text { Велікобританія, } \\
\text { Sasol Germany } \\
\text { GmbH, Германія }\end{array}$ \\
\hline $\begin{array}{l}\text { Wecobee } \\
\text { M, R, S, W }\end{array}$ & $\begin{array}{c}\text { продукти } \\
\text { гідрогенізації } \\
\text { рослинної олії }\end{array}$ & $313 \ldots 318$ & $40 \ldots 45$ & $104 \ldots 113$ & $\begin{array}{l}\text { "Stepan Company } \\
\text { Northfield, III.", } \\
\text { CШA }\end{array}$ \\
\hline \multicolumn{6}{|c|}{ Гідрофільні основи } \\
\hline & & \multicolumn{3}{|c|}{ Температура твердіння } & \\
\hline $\begin{array}{l}\text { желатино- } \\
\text { гліцеринова }\end{array}$ & $\begin{array}{l}\text { желатин, вода, } \\
\text { гліцерин }\end{array}$ & - & - & - & $\begin{array}{l}\text { Україна, Франція, } \\
\text { Росія, Угорщина }\end{array}$ \\
\hline $\begin{array}{c}\text { поліетилен-оксидні } \\
\text { (Carbowax, Scurol, } \\
\text { Postonal) }\end{array}$ & $\begin{array}{c}\text { полімери окису } \\
\text { етилену }\end{array}$ & $288 \ldots 335$ & $15 \ldots 62$ & $59 \ldots 143,6$ & $\begin{array}{l}\text { Україна, Росія, } \\
\text { США, Франція, } \\
\text { Германія та ін. }\end{array}$ \\
\hline \multicolumn{6}{|c|}{ Дифільні основи } \\
\hline emulsogel & $\begin{array}{c}\text { № 1: олія какао, } \\
\text { віск емульсійний, } \\
\text { ПЕО } \\
\text { № 2: твердий жир, } \\
\text { ПЕО, ПАР } \\
\text { № 3: соняшникова } \\
\text { олія, ПЕО, ПАР }\end{array}$ & - & - & - & Україна \\
\hline
\end{tabular}




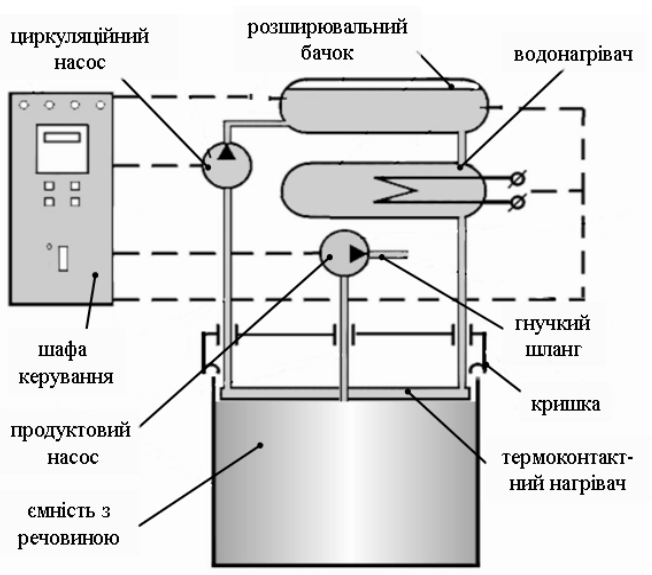

Рис. 3. Принципова схема установки для термоконтактного нагрівання та плавлення.

Особливостями даної установки є те, що в ній об’єднані чотири технологічні операції: плавлення, вивантаження, дозування та транспортування розплавленої речовини в одному технологічному циклі, що дає можливість прискорити розплавлення основи та, як наслідок, зменшити ви- трати енергії. В установці дисковий нагрівач безпосередньо контактує 3 поверхнею основи, яку необхідно розплавити. Спосіб дозволяє нагрівати та розплавляти лише ту частину основи, яка необхідна, тобто реалізовувати дозований процес плавлення, що дає можливість більш раціонально використовувати енергію. При чому температуру дискового нагрівача в зоні контакту з основою підтримують нижчою температури iii деструкції, а на поверхні розплаву - вищою температури іiі плавлення, а завдяки низькому коефіцієнту теплопровідності не перегріваються нижні шари основи під розплавом, що забезпечує необхідні структурно-механічні властивості та високу якість виготовлених супозиторіїв. Також установка забезпечує регулювання температурного режиму, підібраного для супозиторних основ 3 різними теплофізичними властивостями, для забезпечення їх плинності з метою подальшого транспортування їх трубопроводами на наступні стадії виготовлення супозиторіїв $[5,6]$. Переваги такої установки представлено на рис. 4.

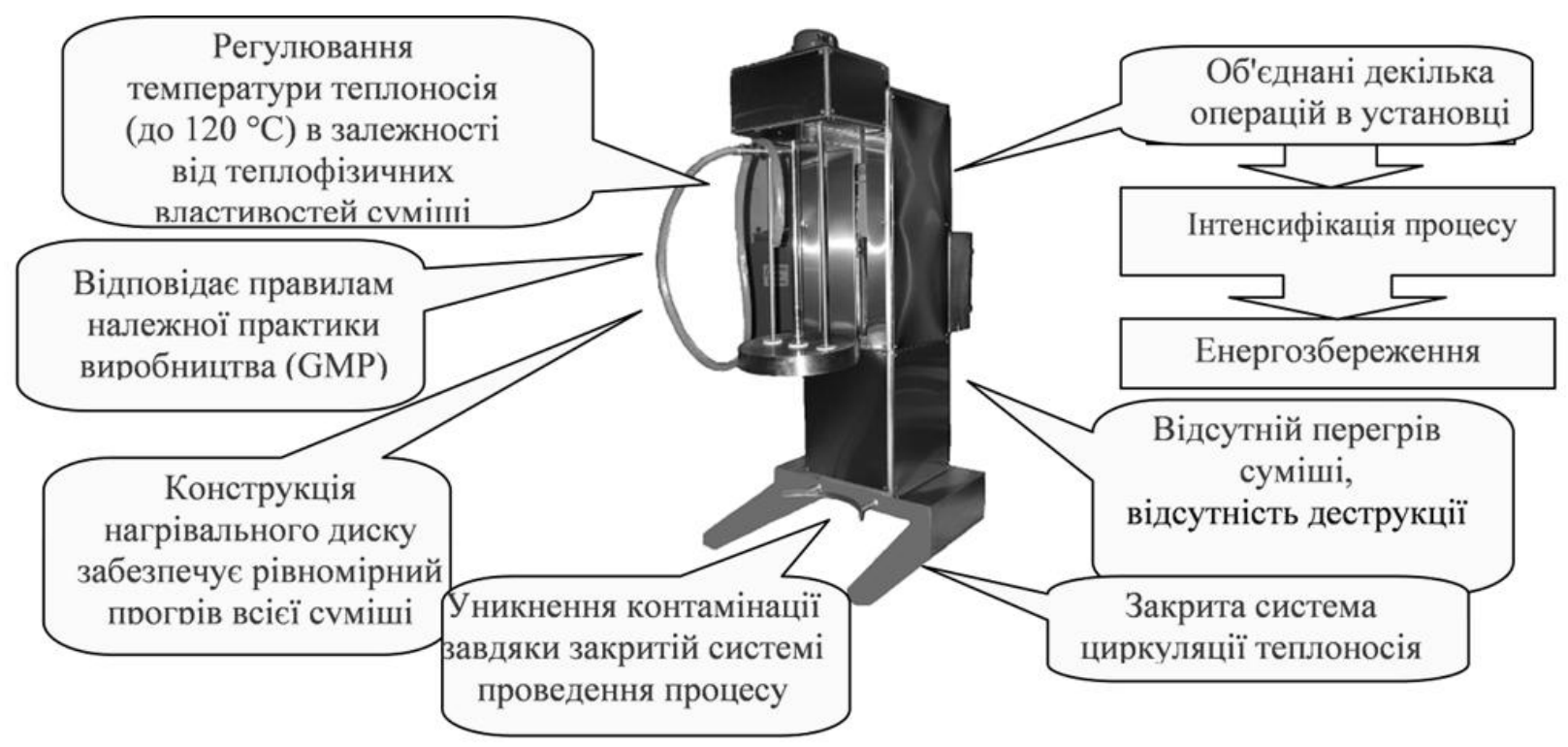

Рис. 4. Переваги установки для термоконтактного нагрівання та плавлення.

На основі проведених експериментальних досліджень методу термоконтактного нагрівання та плавлення отримано графік залежності об'єму розплаву від температури нагрівача (рис. 5) для вибору оптимальних параметрів проведення про- цесу плавлення. Інтенсифікація процесу плавлення досягається збільшенням температури нагрівача, а також створенням однорідного температурного поля на поверхні термоконтактного нагрівача завдяки обраній конструкції. 


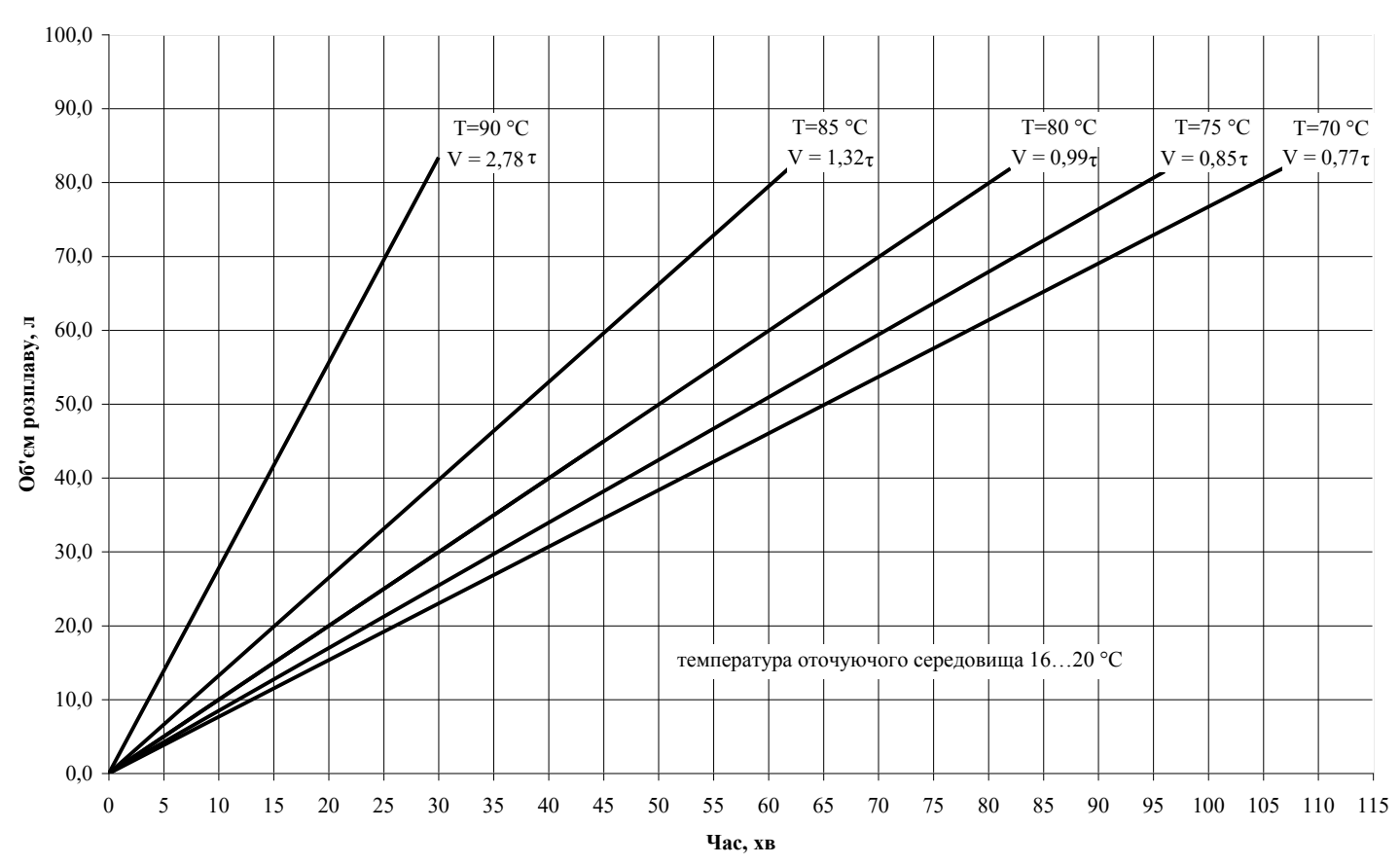

Рис. 5. Графік залежності об’єму розплаву від температури нагрівача.

При дослідженнях 3 використанням тепловізора марки Ті-160 вдалося простежити рух нагрівача по довжині ємності, а також розподілення температур на поверхні термоконтактного нагрівача та всередині металевих ємностей заводу-виробника (рис. 6). Термограми показують рівномірний прогрів термоконтактного нагрівача (рис. 6, a) та всього об’єму розпла- ву при його русі до низу ємності і плавлення основи (рис. 6, б-г). Завдяки низькому коефіцієнту теплопровідності основ вона знаходиться у початковому в'язкому стані, а нагрівається та плавиться при контакті з нагрівачем (рис. 6, в). В кінці процесу (рис. 6, г) спостерігаються конвективні потоки, що сприяє підтриманню температури розплаву на заданому рівні.

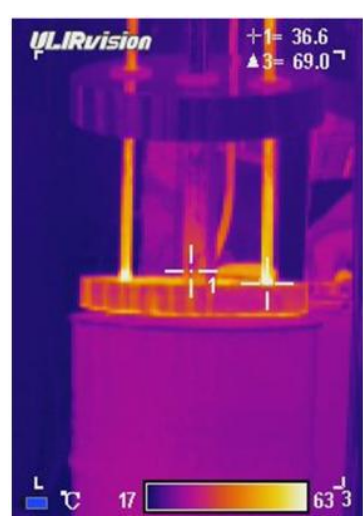

a)

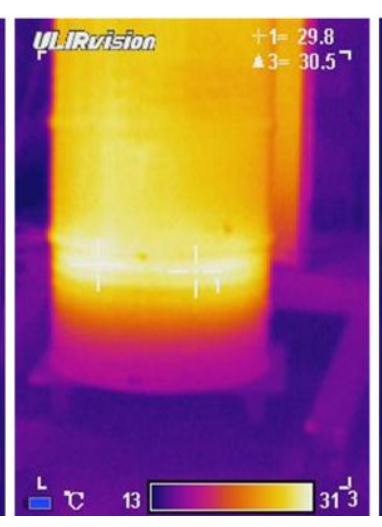

б)

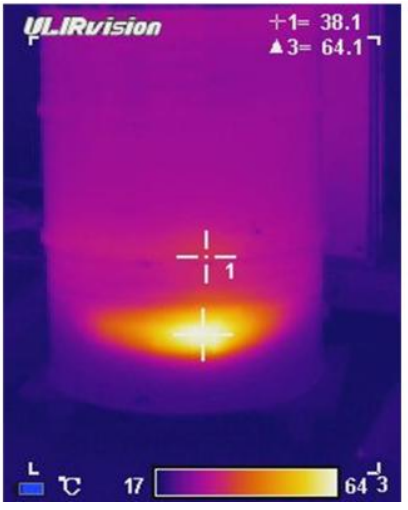

6)

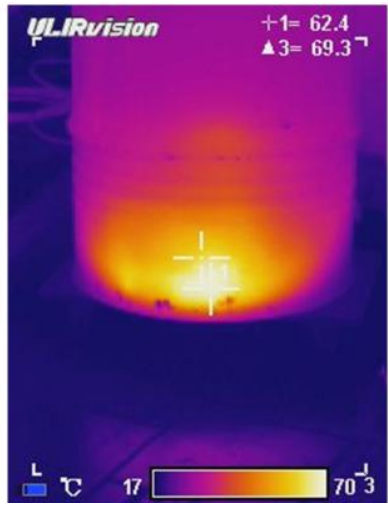

2)

Рис. 6. Термограми процесу термоконтактного нагрівання та плавлення основ в смностях заводу-виробника:

а) прогрів термоконтактного нагрівача; б) початок нагрівання та плавлення;

в) прогрів в процесі опускання термоконтактного нагрівача;

2) закінчення нагрівання та плавлення (термоконтактний нагрівач опустився на дно ємності). 
Установки типу "Термобат" для термоконтактного нагрівання та плавлення основ безпосередньо в металевих бочках заводу-виробника, що відповідають стандартам GMP, Інститутом технічної теплофізики НАН України розроблені та впроваджені на фармацевтичних фабриках: КП "Фармація" “Луганська фармацевтична фабрика", м. Луганськ; АТ "Ризька фармацевтична фабрика", м. Рига; ТОВ “Тернофарм”, м. Тернопіль.

На стадії введення лікарських речовин в основу (рис. 1, стадія III) однією з головних задач $€$ те, щоб лікарські речовини були максимально дисперговані i рівномірно розподілені по всій основі. Особливо важливо це, якщо в складі супозиторіїв присутні як гідрофільні, так і гідрофобні речовини.

За традиційною технологію на фармацевтичних підприємствах для змішування основи 3 лікарськими речовини застосовують реактори 3 різними мішалками. Процес диспергації здійснюють багатоступенево, як правило, на окремих кулькових та молоткових млинах із значною втратою лікарських речовин. Ці подрібнені речовини вводять у розплав i здійснюють подальшу диспергацію на трьохвалкових мазетерках. Як видно, ці операції здійснюють на різному обладнанні, воно періодичної дії та потребує ретельного виконання правил безпеки, бо шкодить здоров'ю обслуговуючого персоналу. При застосуванні способу диспергування механічними, пропелерними, шнековими, турбінними та іншими мішалками, мають місце великі витрати енергії на подолання сил тертя і в'язких сил в тих зонах, де не діють органи мішалки. Також надмірно витрачається енергія при макроперемішуванні всієї маси речовини для того, щоб забезпечити достатню турбулізацію для отримання необхідної гомогенності [7]. В той же час діючі методи не дають можливості змішувати гідрофільні і гідрофобні речовини без розшарування.

Багаторічні дослідження Інститутом технічної теплофізики НАНУ методу дискретноімпульсного введення енергії дозволяють виключити ряд трудомістких операцій в технології отримання ЛФ і проводити процеси перемішування, диспергацій та гомогенізацій в одному апараті, внаслідок чого зменшити тривалість цієї стадії отримання супозиторіїв та витрати електроенергії [8, 9]. Розроблені та створені гомогенізатори-диспергатори, в яких застосовується метод ДІВЕ, різних конструкцій: РПГ-2000, РПГ-2500 М, АР-3000, АР-3000 М для здійснення і інтенсифікації ряду технологічних процесів, таких як, перемішування, диспергування, гомогенізація, емульгування, розчинення, екстракція, гомогенізація та ін. Інтенсифікація хіміко-технологічних процесів у цих апаратах відбувається за рахунок багатофакторного впливу на оброблюване середовище, що полягає в пульсаціях тиску й швидкості потоку, розвиненій турбулентності, інтенсивній кавітації та схлопуванні кавітаційних пухирців, високих зсувних зусиллях тощо.

На таких гомогенізаторах-диспергаторах проводиться обробка твердих речовин з рідкими за рахунок гідродинамічної дії на гетерогенні системи, що запобігає термічній деструкції, перекристалізації та агломерації, і дає можливість отримати більш гомогенну структуру зі значно подрібненими речовинами. Це у свою чергу дає можливість збільшити питому поверхню лікарських речовин в ЛФ і змішати гідрофільні та гідрофобні речовини без розшарування.

Низька енергоємність гомогенізаторівдиспергаторів обумовлена тим, що оброблюване середовище є одночасно і джерелом, і об'єктом гідромеханічних коливань, тобто в таких апаратах відсутні проміжні трансформатори енергії, механічна енергія безпосередньо перетворюється в акустичну й кавітаційну енергію, за рахунок цього ККД дії апарата досить високий.

Гомогенізатор-диспергатор АР-3000 входить до створеного в ІТТФ НАНУ мобільного агрегату типу "Фарматрон-3000", тому що конструктивно він виконаний 3 можливістю підключення до діючого на фармацевтичних підприємствах технологічному обладнанню [8]. Створений агрегат диспергує лікарські речовини 3 основою, підігріває багатокомпонентний розплав i забезпечує транспортування та рециркуляцію розплаву по технологічним трубопроводам. За допомогою цього агрегату було налагоджено виробництво на ВАТ “Монфарм” (м. Монастирище) стабільних супозиторіїв на дифільних основах. 
На якість кінцевого продукту також впливають методи формування супозиторіїв (рис. 1, стадія V): ручне формування (викочування), виливання, пресування, що мають свої недоліки та переваги (рис. 7).
Створене в ІТТФ НАНУ вітчизняне устаткування, яке відповідає вимогам GMP, є конкурентоздатним, впроваджено на фармацевтичних підприємствах нашої країни та експортується.

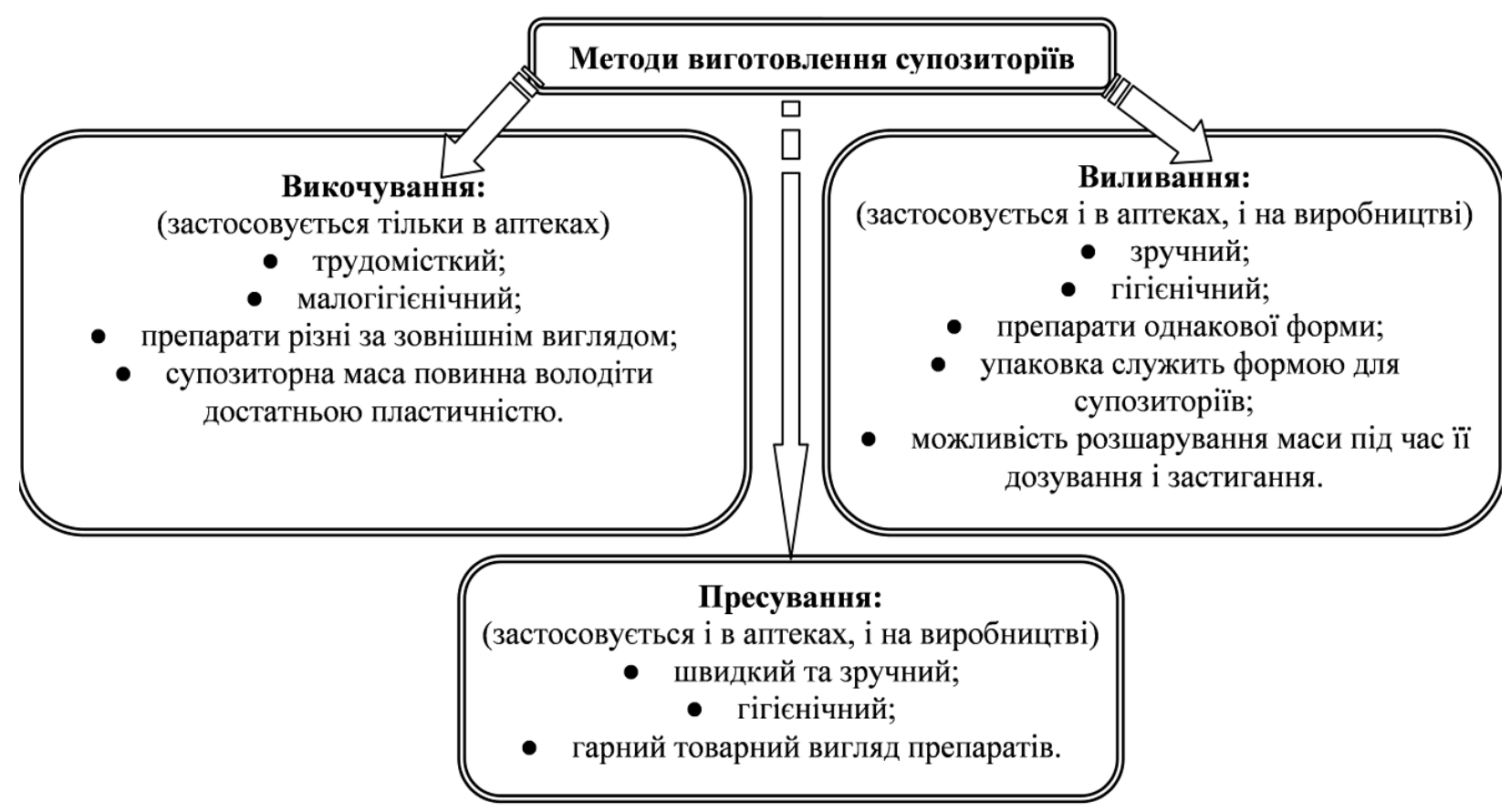

Рис. 7. Переваги та недоліки методів формування супозиторіїв.

\section{Висновки}

1. В Україні необхідно модернізувати діюче устаткування та розробити нове для виготовлення супозиторних форм, що обумовлено відсутністю вітчизняного сучасного енергозберігаючого обладнання у фармацевтичній промисловості, яке відповідало б міжнародним вимогам та правилам належної практики виробництва (GMP).

2. При виготовленні супозиторних форм необхідно дотримуватися вимог до дисперсності, стабільності, однорідності, часу деформації та мікробіологічної чистоти, не допустити контамінації. Для цього використано метод термоконтактного нагрівання та плавлення та метод ДІВЕ.

3. Досвід авторів ІТТФ НАНУ, проведені теоретичні та експериментальні дослідження дозволили розробити ресурсозберігаючу технологію виготовлення високоякісних супо- зиторних форм 3 використанням методів термоконтактного нагрівання та плавлення i дискретно-імпульсного введення енергії та створити високоефективне обладнання для проведення тепломасообмінних процесів нагрівання, плавлення, перемішування, диспергації та гомогенізації при отриманні супозиторних ЛФ. Завдяки використанню методу ДІВЕ можливо змішувати гідрофільні та гідрофобні інгредієнти без розшарування.

\section{ЛІТЕРАТУРА}

1. Периеев І.М., Постольник В.В., Халєєва О.Л. Супозиторні лікарські препарати на ринку України // Вісник фармації. - 2001. - № 1 (25). C. $43-49$.

2. Литвиненко T.M. Сучасний стан асортименту супозиторних основ і фактори їх вибору // Технологія виробництва ліків. - 2014. - № 1 (14). - C. 35-38. 
3. Печенежская Л.А., Тихонова С.А., Писаренко Т.В. Оптимизация процесса термоПиминов А.Ф. и др. Лекарственные препараты контактного плавления материалов // Промышдля ректального применения: Учеб. пособ. Х.: Изд-во НФаУ, 2006. - 56 с.

4. Патент 31435 Україна, МПК7 В $01 \mathrm{~J}$ 6/00. Спосіб плавлення речовини та пристрій для його здійснення/ Грабов Л. М. та інші; заявник та патентовласник: Грабов Л.М., Мерщій B.I., Бондарь С.I. - № 98094668; заявл. 01.09.98; надр. 17.12.01, Бюл. № 11.

5. Долінський А.А., Грабов Л.М., Степанова O.Є. Теплообмін при нагріванні і плавленні основ для виготовлення косметичних та фармацевтичних препаратів // Промышленная теплотехника - 2011. - Т. 33, № 3. - С. 12-19. ленная теплотехника. - 2000. - Т. 22, № 1. C. 94-99.

7. Гаврилов А.С. Фармацевтическая технология. Изготовление лекарственных препаратов: учебник. $-2010 .-624 \mathrm{c}$.

8. Долинский А.А., Грабов Л.Н., Грабова Т.Л. Метод ДИВЭ в инновационных технологиях и тепломассообменном оборудовании // Промышленная теплотехника. -2012 . - Т. 34, № 3. - С. $18-30$.

9. Грабов Л.Н., Мерщий В.И., Посунько Д.В. Диспергирование многокомпонентных гетерогенных систем // Промышленная теплотехника.

6. Грабов Л.Н., Мерщий В.И., Ващенко В.Н., -2008. - Т. 30, № 2. - С. 27-32. 


\section{APPLICATION METHODS OF THERMOCONTACT HEATING AND DISCRETE PULSE INPUT ENERGY IN TECHNOLOGIES OF OBTAINING SUPPOSITORIES}

\section{Grabov L.M., Posun'ko D.V., Stepanova O.E.}

Institute of Engineering Thermophysics of the National Academy of Sciences of Ukraine, vul. Zhelyabova, 2a, Kyiv, 03680, Ukraine

The analysis of the traditional technology of suppository medicinal forms and innovative techniques and equipment that are developed in IET NASU.

References 9, tables 1, figures 7.

Key words: heating, melting, dispersion, homogenization, suppositories, hydrophilic, hydrophobic and diphilic bases.

1. Pertsev I.M., Postol'nyk V.V., Khalyeyeva O.L. Suppository drugs on the market of Ukraine // Visnyk farmatsiyi. - 2001. - № 1 (25). - P. 43-49. (Ukr.)

2. Lytvynenko T.M. Current status range suppository bases and factors of their choice // Tekhnolohiya vyrobnytstva likiv. - 2014. - № 1 (14). - P. 35-38. (Ukr.)
3. Pechenezhskaya L.A., Tykhonova S.A., Pymynov A.F. y dr. Drugs for rectal use: Ucheb. posob. - KH.: Izd-vo NFaU, 2006. - 56 p. (Rus.)

4. Patent 31435 Ukrayina, MPK7 B 01 J 6/00. A method of melting substances and device for its implementation / Grabov L.M. ta inshi; zayavnik ta patentovlasnik: Grabov L.M., Merschiy V.I., Bondar S.I. - № 98094668; zayavl. 01.09.98; nadr. 17.12.01, Byul. № 11. (Ukr.)

5. Dolinsky A.A., Grabov L.M., Stepanova O.E. Heat transfer at heating and fusion of bases for manufacturing of cosmetic and pharmaceutical preparations // Promyshlennaya teplotekhnika. - 2011. - V. 33, № 3. - P. 12-19. (Ukr.)

6. Grabov L.N., Mershchiy V.I., Vashchenko V.N., Pisarenko T.V. Optimization of process thermocontact melting of materials // Promyshlennaya teplotekhnika. - 2000. - V. 22, № 1. - P. 94-99. (Rus.)

7. Gavrilov A.S. Pharmaceutical technology. Production drugs: uchebnik. - 2010. - 624 p. (Rus.)

8. Dolinsky A.A., Grabov L.N., Grabova T.L. Method DPIE in innovative technologies and heat and mass transfer equipment // Promyshlennaya teplotekhnika. - 2012. - V. 34, № 3. - P. 18-30. (Rus.)

9. Grabov L.M., Merschiy V.I., Posun'ko D.V. Dispersing multicomponent heterogeneous systems // Promyshlennaya teplotekhnika. - 2008. - V. 30, № 2. - P. 27-32. (Rus.) 